\title{
A Survey on Corporate Sustainability Reporting: The Case of Iran
}

\author{
Bita Mashayekhi $^{1,}$, , Hossein Shaker Taheri ${ }^{2}$, Mehdi Momeni Taheri ${ }^{2}$ \\ ${ }^{1}$ Department of Accounting, Faculty of Management, University of Tehran, Tehran, Iran \\ ${ }^{2}$ Department of Accounting, Faculty of Management and Accounting, Islamic Azad University-Islamshahr, Tehran, Iran
}

Email address:

mashaykhi@ut.ac.ir (B. Mashayekhi)

${ }^{*}$ Corresponding author

\section{To cite this article:}

Bita Mashayekhi, Hossein Shaker Taheri, Mehdi Momeni Taheri. A Survey on Corporate Sustainability Reporting: The Case of Iran. Journal of Finance and Accounting. Vol. 7, No. 3, 2019, pp. 76-87. doi: 10.11648/j.jfa.20190703.12

Received: May 17, 2019; Accepted: June 17, 2019; Published: June 27, 2019

\begin{abstract}
Today, the issue of corporate sustainability is noted both in academic literature and in the business environment, and there are many companies and organizations that want to make their operations sustainable and communicate different dimensions of sustainability in their business to stakeholders through sustainability reporting. This paper seeks to provide a framework for corporate sustainability reporting by reviewing existing literature on sustainability reporting, taking into account the expertise of domestic experts, to provide a roadmap for developing corporate sustainability reports in Iran. The statistical population of this study includes professionals and academics, including university teachers and post- graduate students in business majors. Our sample was determined via judgment sampling and data was obtained through 119 designed questionnaires. The results of this research is summarized in a Corporate Sustainability Reporting Framework for Iran, which is developed based on Seven research questions related to preparers of sustainability reports; determinants of sustainability reporting; the content of sustainability reports; corporate governance mechanisms necessary for sustainability reporting; challenges and risks with regard to sustainability reporting; benefits of sustainability reports; and assurance of sustainability reports.
\end{abstract}

Keywords: Sustainability Reporting, Corporate Sustainability, Assurance

\section{Introduction}

Corporate sustainability is meeting the desires of direct and indirect stakeholders of the company without compromising on the capability to meet the future stakeholders' needs [1]. Also, corporate sustainability is a process of focusing on company achievements in all five dimensions of sustainable performance (economic, social, managerial, ethical, and environmental) [2]. Today, corporate sustainability has been considered both in academic literature and in the business environment.

A number of sustainability theories have been developed in examining the role of corporations in society and their interactions with their stakeholders, including agency, stakeholder, signaling, institutional, legitimacy, and stewardship theories. According to him, stakeholders consisting of shareholders, creditors, suppliers, customers, employees, government, society and the environment [2]. The aforementioned theories try to explain the integration among several dimensions of sustainability performance, interactions between them, the possible pressures and constraints imposed by them on the key business objective of creating value for its shareholder [2]. For instance, sustainability reporting based on stakeholder and legitimacy theories address a process for protecting the interests of all stakeholders, focusing on achieving long-term financial and non-financial performance for all owners.

Despite the growing trend of presenting sustainability reports by companies and emerging policy makers in this area in many countries, Iran has so far paid less than this, and academic research and systematic reviews of sustainability reporting have not yet been completed. Therefore, important issues in Iranian business environment such as the factors affecting the preparation of sustainability report, its content, the governance mechanisms, related challenges, and its 
assurance remain neglected.

Thus this paper seeks to find out essential and challenging regarding sustainability reporting via reviewing the literature and taking into account experts' opinions, and to propose a conceptual framework for corporate sustainability reporting in Iran.

In the following, the structure of the paper includes an overview of the literature, research questions, research method, research findings, and conclusions.

\section{Literature Review}

In a research, the factors affecting sustainability reporting has been investigated by reviewing 178 research papers from 1999 to 2011 [3]. In this research, the determinants of corporate sustainability reporting divided are divided into internal and external factors. Internal factors include size, financial performance, financial leverage, social and environmental performance, and ownership structure; and external factors are corporate visibility, sector affiliation, country-of-origin, and legal requirements.

According to the research [3], just company size consistently has a positive effect on sustainability reporting as an internal determinant as well as corporate visibility and stakeholder pressure as external ones.

In another study, the challenges regarding generating integrated reports are investigated [4]. Through detailed interviews with those who prepare integrated reports, they find out integrated reporting challenges as follows: (1) a 'push-down' approach for preparing integrated reports; (2) managerial and strategic attitudes; (3) doubts about the relevancy of integrated reports; (4) uncertainty about what should be reported; (5) striking an equilibrium between qualitative and quantitative disclosures; (6) the difficulty of identifying material information for reporting; (7) challenges regarding practical data and system; and (8) and impression management.

Some research has also looked at the factors that trigger demand for sustainability assurance services. According to prior research, larger registered firms in the stock exchange markets have been more in demand for sustainability reporting assurance services ([5-10]) show that US large firms, companies that disclose more information in sustainability reports, and those companies which operate in industries that are sensitive to environmental issues as well as financial industry, are more likely to employ sustainability reporting assurance services.

In Iran, some research has been conducted on corporate sustainability. One of these research develop a model for ranking Iranian listed companies in terms of environmental, social, and governance reporting (ESG) via Analytical Hierarchy Process (AHP). Their results show that social, environmental, and governance dimensions are in the order of priority [11]. The second study examine the variables that affect the sustainability reporting. The results indicate company size, liquidity, institutional shareholders, and CEO duality have a significant effect on the level of corporate sustainability reporting [12].

The third one examine the relationship between firm size, industry type, and profitability with disclosing environmental and social accounting information. Their findings suggest that there is a meaningful positive relationship between size and level of disclosure of environmental and social information, but there is no significant relationship between the level of disclosure of environmental and social information with profitability [13]. In fact, Iranian companies are not interested in this kind of reporting, so there is a real need for much improvement in the disclosure regarding corporate governance, social, and environmental information as the main dimensions of sustainability.

According to Iranian position with regard to sustainability and CSR reporting, developing a conceptual framework for sustainability reporting for Iranian listed firms is a must, and this study tries to do this.

\section{Research Questions}

Considering the literature in sustainability reporting area and taking into account the special conditions of Iran, the following questions on the subject of developing of a sustainability reporting framework in Iran are designed.

1. Who should prepare sustainability reports?

2. What are the drivers and factors affecting sustainability reporting and the reason for sustainability reporting in non-compulsory conditions in Iran?

3. Which information should be disclosed in a sustainability report?

4. Which corporate governance mechanisms encourage the sustainability reporting?

5. What are the challenges and risks surrounding the sustainability reporting?

6. How can companies maximize the benefits of sustainability reporting?

7. Should sustainability reports be audited?

\section{Research Method}

This study, in respect to its goals, is a kind of descriptive research on the one hand, and on the other is exploratory one. This study employs the survey method which is very common method in research. Our survey is performed crosssectional, in which, data is collected just once during a period of time (several days, weeks, or months); and a questionnaire is used to collect the data. In order to design the questionnaire, firstly we review the literature on sustainability reporting. Then, we gather the experts' opinions via a focus group consisting people who involve sustainability activities as well as sustainability reporting. In the next step and based on previous data we developed our questionnaire and tried to cover our research questions through the questionnaire in 72 categories, which are shown in appendix (1). Respondents were offered a choice of five pre-coded responses by using five-point Likert Scale, which is used to allow the individual to express how much they 
agree or disagree with a particular statement.

Afterward we have to test the validity and reliability of the questionnaire. For this purpose, we sent it to 18 experts in the field of sustainability and 10 comments were received from them. After submitting corrective suggestions, the final questionnaire was ready to distribute. Cronbach's alpha coefficient is used for reliability measurements. Considering that the Cronbach's alpha coefficient is $88 \%$, the designed questionnaire has an acceptable reliability.

The questionnaires were distributed electronically to 250 academic and professionals involved in sustainability activities, research, and reporting; and a total of 119 respondents completed the survey $-\mathrm{a} 47.6 \%$ response rate.

\section{Research Findings}

Statistical analysis of collected data from the questionnaires is presented in two sections: descriptive statistics and inferential statistics. Of the 119 respondents, 85 are male and 34 are female; and 26 percent have $\mathrm{PhD}$. Also, 71 respondents are professionals and others are university faculty members. The average age of the respondents is 32.5 years and their average working experience is 15 years.

The results of the analysis of the responses provided to the items related to the first research question are described in Table 1.

Table 1. Research Question 1- Who should prepare sustainability reports?

\begin{tabular}{llllllllll}
\hline Item & Mean & $\begin{array}{l}\text { Std. } \\
\text { Deviation }\end{array}$ & Std. Error & T-Statistic & df & $\begin{array}{l}\text { Significance of } \\
\text { Two Sequences }\end{array}$ & $\begin{array}{l}\text { Mean } \\
\text { Difference }\end{array}$ & $\begin{array}{l}\text { Lower Confidence } \\
\text { Interval }\end{array}$ & $\begin{array}{l}\text { Upper Confidence } \\
\text { Interval }\end{array}$ \\
\hline 1 & 3.13 & 1.193 & 0.109 & 1.230 & 118 & 0.221 & 0.134 & -0.08 \\
2 & 3.50 & 1.134 & 0.104 & 4.769 & 118 & 0.000 & 0.496 & 0.29 \\
3 & 3.25 & 1.223 & 0.112 & 2.249 & 118 & 0.026 & 0.252 & 0.03 \\
4 & 4.33 & 0.855 & 0.078 & 16.944 & 118 & 0.000 & 1.328 & 0.70 \\
\hline
\end{tabular}

The average score of the responses provided to item\#1 does not have a significant difference with 3 . As a result, respondents do not agree or oppose the preparation of sustainability reports by the financial accounting department. On the other hand, the average scores of the responses provided for items \#2 and \#3 has a significant difference with 3, which indicates that respondents agree with the preparation of sustainability reports by the management accounting department or another independent reporting department. Of course, it should be noted that the average score for the item \#2 (management accounting department) is 3.5 and the average score for the item \#3 (integrated reporting department) is 3.25 . However, based on the results of the test for comparing the means of a community, in Table 2 , this mean difference is not statistically significant.

Table 2. Comparison of means test for the choice between preparation of sustainability reports by the management accounting department or another independent reporting department.

\begin{tabular}{lllllll}
\hline Variable & T-Statistic & \multirow{2}{*}{ df } & Significance of Two Sequences & Mean Difference & $\begin{array}{l}\text { Lower Confidence } \\
\text { Interval }\end{array}$ & $\begin{array}{l}\text { Upper Confidence } \\
\text { Interval }\end{array}$ \\
\hline Score Difference & 1.561 & 118 & 0.121 & 0.244 & -0.065 & 0.553 \\
\hline
\end{tabular}

The results of the analysis of the responses provided to the items related to the first research question are described in Table 3 .

Table 3. Research Question 2-What are the drivers and factors affecting sustainability reporting and the reason for sustainability reporting in non-compulsory conditions in Iran?

\begin{tabular}{|c|c|c|c|c|c|c|c|c|c|}
\hline Item & Mean & $\begin{array}{l}\text { Std. } \\
\text { Deviation }\end{array}$ & $\begin{array}{l}\text { Std. } \\
\text { Error }\end{array}$ & T-Statistic & df & $\begin{array}{l}\text { Significance of } \\
\text { Two Sequences }\end{array}$ & $\begin{array}{l}\text { Mean } \\
\text { Difference }\end{array}$ & $\begin{array}{l}\text { Lower Confidence } \\
\text { Interval }\end{array}$ & $\begin{array}{l}\text { Upper Confidence } \\
\text { Interval }\end{array}$ \\
\hline 5 & 4.25 & 0.704 & 0.065 & 19.409 & 118 & 0.000 & 1.252 & 1.12 & 1.38 \\
\hline 6 & 3.76 & 0.851 & 0.078 & 9.805 & 118 & 0.000 & 0.765 & 0.61 & 0.92 \\
\hline 7 & 3.91 & $1 / 000$ & 0.092 & 9.901 & 118 & 0.000 & 0.908 & 0.73 & 1.09 \\
\hline 8 & 3.88 & 0.865 & 0.079 & 11.124 & 118 & 0.000 & 0.0 .882 & 0.73 & 1.04 \\
\hline 9 & 3.95 & 0.832 & 0.076 & 12.449 & 118 & 0.000 & 0.950 & 0.80 & 1.10 \\
\hline 10 & 3.55 & 0.954 & 0.087 & 6.243 & 118 & 0.000 & 0.546 & 0.37 & 0.72 \\
\hline 11 & 3.60 & 0.986 & 0.090 & 6.603 & 118 & 0.000 & 0.597 & 0.42 & 0.78 \\
\hline 12 & 3.72 & 0.911 & 0.083 & 8.657 & 118 & 0.000 & 0.723 & 0.56 & 0.89 \\
\hline 13 & 3.55 & 0.810 & 0.074 & 7.471 & 118 & 0.000 & 0.555 & 0.41 & 0.70 \\
\hline 14 & 3.27 & 0.936 & 0.086 & 3.134 & 118 & 0.002 & 0.269 & 0.10 & 0.44 \\
\hline 15 & 4.11 & 0.900 & 0.083 & 13.445 & 118 & 0.000 & 1.109 & 0.95 & 1.27 \\
\hline 16 & 3.84 & 0.792 & 0.073 & 11.578 & 118 & 0.000 & 0.840 & 0.70 & 0.98 \\
\hline 17 & 3.92 & 0.962 & 0.088 & 10.389 & 118 & 0.000 & 0.916 & 0.74 & 1.09 \\
\hline
\end{tabular}

The average of the responses provided to items \#5 to \#17 has a significant difference with 3 , therefore, from the respondents' point of view, the factors mentioned in these items are effective on sustainability reporting and are considered as sustainability reporting determinants. Since the effects of large companies and companies operating in 
environmentally sensitive industries are being monitored by the various groups of the public communities and the media, and consequently the society is more sensitive to the activities of these companies, the mentioned items have obtained more scores in our questionnaire. A similar argument can be made for the high score for the registered companies in the stock exchange. Also, the fact that the company name is identical to its brand name has the lower the score because in Iranian business environment, companies' brands and reputation are probably not considered by the society similar to developed countries.

The results from the analysis of the responses provided to the items related to the third research question are described in Table 4.

Table 4. Research Question 3- Which information should be disclosed in a sustainability report?

\begin{tabular}{|c|c|c|c|c|c|c|c|c|c|}
\hline Item & Mean & $\begin{array}{l}\text { Std. } \\
\text { Deviation }\end{array}$ & Std. Error & T-Statistic & df & $\begin{array}{l}\text { Significance of } \\
\text { Two Sequences }\end{array}$ & $\begin{array}{l}\text { Mean } \\
\text { Difference }\end{array}$ & $\begin{array}{l}\text { Lower Confidence } \\
\text { Interval }\end{array}$ & $\begin{array}{l}\text { Upper Confidence } \\
\text { Interval }\end{array}$ \\
\hline 18 & 2.93 & 1.095 & 0.100 & -0.670 & 118 & 0.504 & -0.067 & -0.27 & 0.13 \\
\hline 19 & 3.45 & 1.047 & 0.096 & 4.640 & 118 & 0.000 & 0.445 & 0.26 & 0.64 \\
\hline 20 & 4.22 & 0.958 & 0.088 & 13.873 & 118 & 0.0 .000 & 1.218 & 1.04 & 1.39 \\
\hline 21 & 3.24 & 1.207 & 0.111 & 2.202 & 118 & 0.030 & 0.244 & 0.02 & 0.46 \\
\hline 22 & 3.21 & 0.919 & 0.084 & 2.493 & 118 & 0.014 & 0.210 & 0.04 & 0.38 \\
\hline 23 & 3.53 & 0.891 & 0.082 & 6.483 & 118 & 0.000 & 0.529 & 0.37 & 0.69 \\
\hline 24 & 3.22 & 1.106 & 0.101 & 2.155 & 118 & 0.033 & 0.218 & 0.02 & 0.42 \\
\hline 25 & 3.61 & 0.950 & 0.087 & 6.950 & 118 & 0.000 & 0.605 & 0.43 & 0.78 \\
\hline 26 & 4.08 & 0.743 & 0.068 & 15.914 & 118 & 0.000 & 1.084 & 0.95 & 1.22 \\
\hline
\end{tabular}

According to the results, respondents do not agree or disagree with the three-dimensional sustainability reporting model (ESG), and the scores given to this sustainability reporting model do not differ significantly with 3 . Nevertheless, the scores given by respondents to the fourdimensional and five-dimensional models differ significantly from the respondents' point of view. The result from the comparison of means tests, as is shown in Table 5, shows that the mean scores related to the five-dimensional model are significantly higher than others. As a result, respondents consider ethical dimension as one of the dimensions of sustainability reporting.

Table 5. Comparison of means test for the choice between the four-dimensional and five-dimensional sustainability reporting models.

\begin{tabular}{llllll}
\hline Variable & T-Statistic & df & Significance of Two Sequences & Mean Difference & $\begin{array}{l}\text { Lower Confidence } \\
\text { Interval }\end{array}$ \\
\hline Score Difference & 5.317 & 118 & 0.000 & -0.773 & -1.061 \\
Interval
\end{tabular}

Items \#21 to \#25 relate to preferred dimensions for reporting in sustainability reports. The analysis of the responses shows that almost all respondents agree to provide information on all dimensions of sustainability reporting including economic, governance, social, and environmental. The analysis of the responses provided to item \#26 also indicates the respondents demand for information regarding sustainability risks in sustainability reports. This implies an emphasis on a broad range of risk management, which means that companies need to manage and report all risks in order to achieve their goals and be sustainable.

The results of the analysis of the responses with regard to the fourth research questions are as follow (Table 6).

Table 6. Research Question 4- Which corporate governance mechanisms encourage the sustainability reporting?

\begin{tabular}{llllllllll}
\hline Item & Mean & $\begin{array}{l}\text { Std. } \\
\text { Deviation }\end{array}$ & Std. Error & T-Statistic & df & $\begin{array}{l}\text { Significance of } \\
\text { Two Sequences }\end{array}$ & $\begin{array}{l}\text { Mean } \\
\text { Difference }\end{array}$ & $\begin{array}{l}\text { Lower Confidence } \\
\text { Interval }\end{array}$ & $\begin{array}{l}\text { Upper Confidence } \\
\text { Interval }\end{array}$ \\
\hline 27 & 4.02 & 0.813 & 0.075 & 13.646 & 118 & 0.000 & 1.017 & 0.87 \\
28 & 4.13 & 0.853 & 0.078 & 14.509 & 118 & 0.000 & 1.134 & 0.98 \\
29 & 3.53 & 0.910 & 0.083 & 6.349 & 118 & 0.000 & 0.529 & 0.36 \\
30 & 3.96 & 0.643 & 0.059 & 16.252 & 118 & 0.000 & 0.958 & 0.84 \\
31 & 4.04 & 0.643 & 0.059 & 17.678 & 118 & 0.000 & 1.042 & 0.93 \\
32 & 4.23 & 0.589 & 0.054 & 22.740 & 118 & 0.000 & 1.227 & 1.12 \\
33 & 4.36 & 0.548 & 0.050 & 27.089 & 118 & 0.000 & 1.361 & 1.07 \\
34 & 4.25 & 0.540 & 0.050 & 25.284 & 118 & 0.000 & 1.26 & 1.252 & 1.15 \\
\hline
\end{tabular}

The mean of the responses provided to items \#27 through \#34 has a significant difference with 3 , so from the respondents' point of views, all mentioned factors are essential for sustainability reporting; accordingly, legal requirement, national and international standards, good corporate governance mechanisms, changing management's attitudes, good information systems infrastructure, and proper strategies are the key sustainability reporting factors, which if not, there will be no mechanism for collecting and presenting information apropos sustainability.

The results of the analysis of the responses with respect to the fifth research questions are as follow (Table 7). 
Table 7. Research Question 5- What are the challenges and risks surrounding the sustainability reporting?

\begin{tabular}{llllllllll}
\hline Item & \multirow{2}{*}{ Mean } & Std. Deviation & Std. Error & T-Statistic & df & $\begin{array}{l}\text { Significance of } \\
\text { Two Sequences }\end{array}$ & $\begin{array}{l}\text { Mean } \\
\text { Difference }\end{array}$ & $\begin{array}{l}\text { Lower Confidence } \\
\text { Interval }\end{array}$ & $\begin{array}{l}\text { Upper Confidence } \\
\text { Interval }\end{array}$ \\
\hline 35 & 4.08 & 0.671 & 0.062 & 17.618 & 118 & 0.000 & 1.084 & 0.96 & 1.21 \\
36 & 4.06 & 0.655 & 0.060 & 17.641 & 118 & 0.000 & 1.059 & 0.94 & 1.18 \\
37 & 4.11 & 0.661 & 0.061 & 18.302 & 118 & 0.000 & 1.109 & 0.99 & 1.23 \\
38 & 3.92 & 0.732 & 0.067 & 13.658 & 118 & 0.000 & 0.916 & 0.78 & $1 / 05$ \\
39 & 4.28 & 0.0 .551 & 0.051 & 25.280 & 118 & 0.000 & 1.277 & 1.18 & 1.38 \\
40 & 4.00 & 0.582 & 0.053 & 18.736 & 118 & 0.000 & 1.000 & 0.89 & 1.11 \\
41 & 3.91 & 0.873 & 0.080 & 11.337 & 118 & 0.000 & 0.908 & 0.75 & 1.07 \\
42 & 4.29 & 0.558 & 0.051 & 25.312 & 118 & 0.000 & 1.294 & 1.19 & 1.40 \\
43 & 4.22 & 0.715 & 0.066 & 18.591 & 118 & 0.000 & 1.218 & 1.09 & 1.35 \\
44 & 3.62 & 1.120 & 0.103 & 6.057 & 118 & 0.000 & 0.622 & 0.42 & 0.83 \\
\hline
\end{tabular}

The analysis of the responses provided to items \#35 to \#44 shows that according to the research participants, the lack of necessary infrastructure in the company's information systems, the lack of accepted standards for sustainability reporting, the high cost of providing sustainability reports, the doubt consequences of the sustainability information disclosure, making a proper balance between quantitative and qualitative sustainability information, and the perspectives of suppliers of sustainability reports that this information is not useful to stakeholders, are considered as challenges and risks surrounding the sustainability reporting.

The statistical analysis of the responses to items \#45 to \#51 related to the sixth research question is described in Table (8).

Table 8. Research Question 6- How can companies maximize the benefits of sustainability reporting?

\begin{tabular}{|c|c|c|c|c|c|c|c|c|c|}
\hline Item & Mean & Std. Deviation & Std. Error & T-Statistic & df & $\begin{array}{l}\text { Significance of } \\
\text { Two Sequences }\end{array}$ & $\begin{array}{l}\text { Mean } \\
\text { Difference }\end{array}$ & $\begin{array}{l}\text { Lower Confidence } \\
\text { Interval }\end{array}$ & $\begin{array}{l}\text { Upper Confidence } \\
\text { Interval }\end{array}$ \\
\hline 45 & 3.58 & 1.077 & 0.099 & 5.870 & 118 & 0.000 & 0.580 & 0.38 & 0.78 \\
\hline 46 & 3.88 & 0.738 & 0.068 & 13.034 & 118 & 0.000 & 0.882 & 0.75 & 1.02 \\
\hline 48 & 3.97 & 0.712 & 0.065 & 14.801 & 118 & 0.000 & 0.966 & 0.84 & 1.10 \\
\hline 49 & 3.83 & 1.028 & 0.094 & 8.830 & 118 & 0.000 & 0.832 & 0.65 & 1.02 \\
\hline 50 & 4.34 & 0.574 & 0.053 & 25.554 & 118 & 0.000 & 1.345 & 1.24 & 1.45 \\
\hline
\end{tabular}

According to the results reported in Table 8, the research participants believe that companies can take more advantage of sustainability reporting via the establishment of appropriate infrastructure regarding information systems and reporting process, as well as strengthening management attitude in all dimensions of sustainable performance. Conversely, through the voluntary disclosure like voluntarily sustainability reporting, companies will benefit less.

In the the statistical results with regard to seventh research question are shown.

Table 9. Research Question 7- Should sustainability reports be audited?

\begin{tabular}{|c|c|c|c|c|c|c|c|c|c|}
\hline Item & Mean & $\begin{array}{l}\text { Std. } \\
\text { Deviation } \\
\end{array}$ & $\begin{array}{l}\text { Std. } \\
\text { Error } \\
\end{array}$ & T-Statistic & df & $\begin{array}{l}\text { Significance of } \\
\text { Two Sequences }\end{array}$ & $\begin{array}{l}\text { Mean } \\
\text { Difference }\end{array}$ & $\begin{array}{l}\text { Lower Confidence } \\
\text { Interval }\end{array}$ & $\begin{array}{l}\text { Upper Confidence } \\
\text { Interval }\end{array}$ \\
\hline 52 & 4.04 & 0.995 & 0.091 & 11.426 & 118 & 0.000 & 1.042 & 0.86 & 1.22 \\
\hline 53 & 4.01 & 1.046 & 0.096 & 10.521 & 118 & 0.000 & 1.008 & 0.82 & 1.20 \\
\hline 54 & 3.73 & 1.006 & 0.092 & 7.929 & 118 & 0.000 & 0.731 & 0.55 & 0.91 \\
\hline 55 & 3.50 & 1.255 & 0.115 & 4.311 & 118 & 0.000 & 0.496 & 0.27 & 0.72 \\
\hline 56 & 3.99 & 0.987 & 0.090 & 10.958 & 118 & 0.000 & 0.992 & 0.81 & 1.17 \\
\hline 57 & 2.93 & 1.006 & 0.092 & -0.729 & 118 & 0.468 & -0.067 & -0.25 & 0.12 \\
\hline 58 & 2.96 & 1.160 & 0.106 & -0.395 & 118 & 0.693 & -0.042 & -0.25 & 0.17 \\
\hline 59 & 2.57 & 1.022 & 0.094 & -4.576 & 118 & 0.000 & -0.429 & -0.61 & -0.24 \\
\hline 60 & 2.73 & 0.989 & 0.091 & -2.966 & 118 & 0.004 & -0.0 .269 & -0.45 & -0.09 \\
\hline 61 & 3.71 & 0.967 & 0.089 & 8.060 & 118 & 0.000 & 0.714 & 0.54 & 0.89 \\
\hline 62 & 3.29 & 1.084 & 0.099 & 2.959 & 118 & 0.004 & 0.294 & 0.10 & 0.49 \\
\hline 63 & 3.27 & 1.102 & 0.101 & 2.661 & 118 & 0.009 & 0.269 & 0.07 & 0.47 \\
\hline 64 & 2.71 & 1.152 & 0.106 & -2.784 & 118 & 0.006 & -0.294 & -0.50 & -0.08 \\
\hline 65 & 2.62 & 1.058 & 0.097 & -3.901 & 118 & 0.000 & -0.378 & -0.57 & -0.19 \\
\hline 66 & 2.55 & 1.031 & 0.094 & -4.713 & 118 & 0.000 & -0.445 & -0.63 & -0.26 \\
\hline 67 & 2.08 & 0.855 & 0.078 & -11.790 & 118 & 0.000 & -0.924 & $-1 / 08$ & -0.77 \\
\hline 68 & 2.61 & 1.009 & 0.093 & -4.178 & 118 & 0.000 & -0.387 & -0.57 & -0.20 \\
\hline 69 & 2.37 & 0.735 & 0.067 & -9.355 & 118 & 0.000 & -0.630 & -0.76 & -0.50 \\
\hline 70 & 3.16 & 0.911 & 0.084 & 1.912 & 118 & 0.058 & 00.60 & -0.01 & 0.33 \\
\hline 71 & 2.94 & 0.866 & 0.079 & -0.741 & 118 & 0.460 & -0.059 & -0.22 & 0.10 \\
\hline 72 & 3.01 & 0.952 & 0.087 & 0.096 & 118 & 0.923 & 0.008 & -0.16 & 0.18 \\
\hline
\end{tabular}


In items $\# 52$ to $\# 55$, the attitude of research participants about auditing the sustainability reports is similar to financial statement auditing and they justify the need for auditing sustainability reports as they do for financial statements audit. Also, according to them, increasing credibility of sustainability reports is a good reason for auditing these kind of reports.

As per, participants in this study comment about the reasons and determinants of demand for auditing the sustainability reports via responding to items \#57 to \#61 are. Accordingly, they disagree with the pressures of media and public thoughts, as well as considering the stakeholder rights as determinants of demanding for auditing sustainability reports. Instead, increasing the value of the firm due to the audit of sustainability reports is the only effective factor on auditing sustainability reports in their opinion.

In our questionnaire, items \#62 to \#69 address the challenges of sustainability reporting audit. In conformity with the respondents believe that due to the lack of local/national standards for sustainability reporting, independent audit of sustainability reports is not possible and this would be a challenge or obstacle for this kind of reporting. On the other hand, respondents oppose the fact that factors include high auditing costs; incapability of the existing supporting systems and processes; lack of mandatory and regulatory requirements; risk of issuing qualified or even adverse audit opinion; lack of accepted and integrated reporting standards; and the existence of alternative procedures are significant obstacles for independent auditing of sustainability reports.

We ask the research participants to determine the alternatives to independent auditing of sustainability reports using items $\# 70$ to $\# 72$. As it is already-mentioned, respondents do not consider the existence of alternative procedures as an obstacle to independent auditing sustainability reports. Consequently, so from the point of view of the respondents are indifferent to alternative procedures independent auditing of sustainability reports like internal audit, self-assurance, or communication with stakeholders for taking their views about companies' sustainable performance.

\section{Discussion}

In this paper, in view of its objective of providing a corporate sustainability reporting framework in Iran, seven research questions are developed based on the literature, and via a survey and in the form of a questionnaire, the opinions and attitudes of the relevant experts are obtained. In light of the responses provided by the experts, a conceptual framework for sustainability reporting in Iran is developed as follows in Figure.

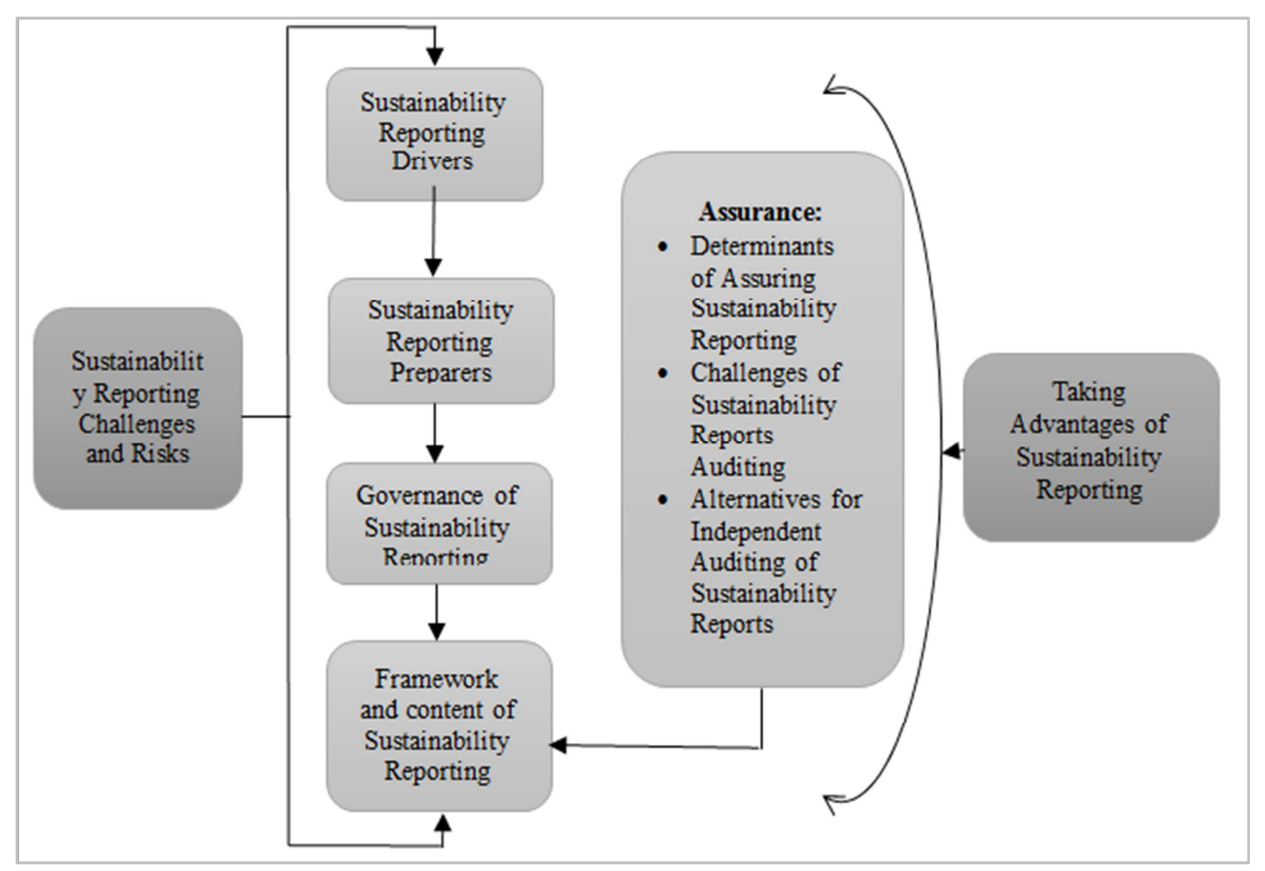

Figure 1. A Framework for Sustainability Reporting in Iran.

Considering the theoretical framework, research literature, and the findings of the present study, the above-mentioned conceptual framework for sustainability reporting in Iran is explained more detailed below.

\subsection{Stability Reporting Determinants}

The first determinant of sustainability reporting is the size of companies. The impact of large companies on the society, their operation visibility, and the careful consideration of these companies by stakeholders are witnesses to this claim as they are motives for sustainability reporting. This result is similar to the research [14] and the study [15]. Since the company's profitability and financial capability lead to firms' flexibility to bear the costs of sustainability reporting, 
profitability and financial capability is considered as the second determinant for the sustainability reporting, which is in line with the studies of the research [16-18]. Being registered in the stock exchange as a public company, due to the adoption of some reporting procedures by competitors, is the third determinant for the sustainability reporting. This result is in accordance with the study [19].

The company's activity in environmental and socially sensitive industries is considered as the forth determinant for the sustainability reporting. This is because the before-mentioned companies are under a significant pressure from their stakeholders. This result is similar to the study [20, 21]. Also, our findings show the culture and social norms as well as regulatory structure of the company's business location are also mentioned as the Fifth and sixth determinants for the sustainability reporting, which are in line with the study [21, 22].

Due to identified determinants for sustainability reporting in Iranian context, the Iranian supervisory and regulatory bodies should provide the necessary background for the reporting sustainability information by companies, and at the same time establish some requirements and regulation or even laws for those companies which are more capable for sustainability activities and reporting.

\subsection{Preparers of Sustainability Reports}

There are different departments in companies that can be considered responsible for preparing sustainability reports. Nevertheless, according to our findings, management accounting department or another reporting departmentexcept for financial accounting - is responsible for sustainability reporting. It should be noted that the ultimate responsibility of sustainability reports is with the board of directors. Certainly, companies and professional institutions should provide the necessary background like required training for those personnel who prepare of sustainability reports.

\subsection{Governance of Sustainability Reporting}

According to our results, sustainability reports should be considered in the context of some governance mechanisms such as legal requirements, national and international standards, management attitude, appropriate information system infrastructure, and the existence of sustainable performance strategies, as well as application of corporate governance principles. In this regard, it is necessary to formulate and approve appropriate legal requirements to facilitate sustainability reporting. Correspondingly, companies should plan for improving their own information systems in order to support the various dimensions of sustainable performance.

\subsection{Sustainability Reports Content}

As per our survey results, although research participants agreed with both five-dimensional and four-dimensional sustainability reporting model, they significantly tended to have the five-dimensional model in comparison to the four- dimensional model. Therefore, it seems sustainability reports in the Iranian setting should include economic, strategic, social, ethical, and environmental information. This preferred five-dimensional model is similar to the model presented in the study [2].

\subsection{External Assurance of Sustainability Reports}

Regarding the external assurance of sustainability reports, issues including incentives/ determinants, challenges, and alternative approaches need to be considered. In conformity with our study, improving the credibility of sustainability reports and increasing firm value are drivers for auditing sustainability reports. The lack of accepted national or international standards for preparing sustainability reports together with the lack of certified sustainability report auditors are considered as the main challenges for sustainability reports auditing. In this respect, professional associations and standardizing bodies should develop guidelines and standards for sustainability reporting auditing. They also should train the concepts of sustainability to the auditors, as well as familiarize them with the application of those guidelines and standards.

On the subject of alternative approaches to independent auditing of sustainability reports, the participants do not consider any alternatives. This finding is Contradictory to the study [23-25] which identifies some alternative procedures like internal audit, self-assurance through some certifications such as ISO, and communication with stakeholders for taking their views about companies' sustainable performance. Immature internal auditing profession in Iran, as well as ineffective communication between companies' management and its stakeholders in Iran are among the factors that have led respondents to oppose independent sustainability reporting alternatives [26].

\subsection{Challenges and Risks of Sustainability Reporting}

The sustainability reporting is a challenging and risky process. According to participants' perspective in this study, the challenges and risks on the subject of sustainability reporting include (1) the lack of required information systems infrastructure, (2) the lack of accepted standards for sustainability reporting, (3) the high cost of sustainability reporting [27], (4) the doubt about consequences of the sustainability information disclosure, (5) the difficulty of making a proper balance between quantitative and qualitative sustainability information, (6) the perspectives of suppliers of sustainability reports that this information is not useful to stakeholders, (7) the viewpoint of some managers regarding the priority and importance of providing financial information in comparison with sustainability information, (8) lack of communication and coordination between different contributing teams in sustainability reporting, (9) lack of active engagement with stakeholders, and (10) the fact that top management requires providing sustainability reports [4] (management push-down approach,). These finding are somehow similar to the study [4], which show 
about challenges of integrated reporting.

\subsection{Taking Advantages of Sustainability Reporting}

In accordance with the results of this survey, companies can take more advantages of sustainability reporting in some ways, including (1) disclosing more voluntary sustainability information; (2) utilizing accepted international standards of sustainability reporting; (3) best practice benchmarking sustainability reports; (4) stakeholder engagement in sustainability reporting process; (5) independent auditing of sustainability reports; (6) establishing appropriate infrastructure for information systems and reporting process; and (7) strengthening management attitudes in all aspects of sustainable performance. However, some aforenoted items are more effective whereas some are less.

Improving the credibility of sustainability reports and increasing firm value are drivers for auditing sustainability reports. The lack of accepted national or international standards for preparing sustainability reports together with the lack of certified sustainability report auditors are considered as the main challenges for sustainability reports auditing. As some other challenges we can refer to the lack of required information systems infrastructure and accepted standards for sustainability reporting; the high cost of sustainability reporting; and the doubt about consequences of the sustainability information disclosure.

\section{Conclusion and Recommendations}

In this study, we tried to review sustainability reporting in Iran after reviewing the sustainability reporting literature around the world. To this end, by analyzing the questionnaire sent to experts in this area, we analyzed their views on the various dimensions of sustainability reporting. The result of this analysis led to the presentation of a conceptual framework explained in the previous section. The summary of this framework is as follows. Some determinant of sustainability reporting based on our results are size of companies; the company's profitability and financial capability, and their presence in environmental and socially sensitive industries; and the culture and social norms. Also, management accounting department or another reporting department- except for financial accounting - is responsible for sustainability reporting, however, the ultimate responsibility of sustainability reports is with the board of directors. As per our results, sustainability reports should be considered in the context of some governance mechanisms such as legal requirements, national and international standards, management attitude, appropriate information system infrastructure, and the existence of sustainable performance strategies, as well as application of corporate governance principles. Furthermore, it seems sustainability reports in the Iranian setting should include economic, strategic, social, ethical, and environmental information.

Finally, Iranian companies can take more advantages of sustainability reporting in some ways like disclosing more voluntary sustainability information, utilizing accepted international standards of sustainability reporting, and strengthening management attitudes in all aspects of sustainable performance. To put the main point in nutshell, the conceptual framework presented in this research can provide a guideline for regulators and standard setters for legislating and policy making regarding sustainability reporting. Furthermore, companies can use this framework to design and shape extract their corporate sustainability reports appropriately in a way which is suitable for Iranian context.

What's more, researchers may apply our proposed conceptual framework for conducting future research in the sustainability reporting areas. Nonetheless, it should be noted that due to our research methodology, including the use of a judgmental sample to increase the validity of the results, the generalizability limitations of the results should be considered.

\section{Appendix: Research Questions}

\section{Research Question 1: Who should prepare sustainability reports?}

1 Sustainability reports should be prepared by the financial accounting department.

2 Sustainability reports should be provided by the management accounting department.

3 Sustainability reports should be provided by an independent department (e.g. the integrated reporting department, if any).

4 The board of directors is responsible for producing sustainability reports as well as financial statements.

Research Question 2: What are the drivers and factors affecting sustainability reporting and the reason for sustainability reporting in non-compulsory conditions in Iran?

5 Size, visibility, and the pressures and demands of their stakeholders to thoroughly examine those companies are drivers of sustainability reporting.

6 Profitability, capability and flexibility of companies regarding sustainability reporting costs are the drivers of sustainability reporting.

7 The legitimization of company activities for creditors and shareholders is a determinant for sustainability reporting.

8 Reducing the information asymmetry between the company and its investors as well as signaling to the market are the drivers of sustainability reporting. 
Registering companies in the stock exchanges (due to the adoption of some reporting procedures by competitors, and therefore, competitive pressure with regard to reporting) is a determinant for sustainability reporting.

The decentralization of the company's ownership structure is a determinant for sustainability reporting due to the lack of major shareholders who already have access to relevant information and the need to reduce information asymmetries.

Ownership of the foreign investors in the company is a determinant for sustainability reporting due to the difficulties in accessing information through alternative sources of information.

12 The attention of the media to the company's activities is a determinant for sustainability reporting.

13 The position of the company in the supply chain is a factor in driving sustainability reporting due to the difference in the relationship between the companies in the supply chain with the final consumers.

Uniformity of the company name and its brands is a driver for sustainability reporting because of its impact on the company's visibility.

The company's activity in environmental and social sensitive industries and their stakeholder pressures is driving sustainability reporting.

16 The culture, social norms, and the local regulatory structure are determining the sustainability reporting.

17 The positive effects of sustainability reporting on the value of the company are determinants of sustainability reporting.

Question 3: Which information should be disclosed in a sustainability report?

18 Sustainability reports should include three dimensions: environmental, social, and governance (ESG).

19 Sustainability reports should include four dimensions: economic, governance, social, and environmental.

20 Sustainability reports should include five dimensions: economic, governance, social, ethical, and environmental.

21 Sustainability reports should prioritize financial and economic performance data.

22 In Sustainability reports, the priority should be given to the presentation of corporate governance information.

23 In sustainability reports, the priority should be given to communicating social performance information (the quality of the implementation of the company's social responsibilities and goals in practice and aligning them with the goals of society).

24 In sustainability reports, the priority must be given to the presentation of ethical performance (the existence of a corporate culture based on integrity and competency).

25 In sustainability reports the priority must be given to the environmental performance data.

26 Sustainability reports should include the risks associated with sustainability performance.

Question 4: Which corporate governance mechanisms encourage the sustainability reporting?

27 It is difficult to prepare sustainability reports without legal requirements.

28 The existence of a legal requirement will increase sustainability reporting and improve its quality.

29 Sustainability reporting using international norms and standards is appropriate for Iranian companies.

30 It is difficult to prepare sustainability reports without any local standards.

31 Sustainability reporting requires the proper implementation of corporate governance principles.

32 Sustainability reporting requires managers to change their attitudes toward reporting and sustainability management.

33 Sustainability reporting is difficult without proper information systems infrastructure.

34 Sustainability reporting requires proper strategies for sustainability in companies.

Question 5: What are the challenges and risks surrounding the sustainability reporting?

35 The fact that top management requires sustainability reporting, is one of the challenges regarding this kind of reporting.

Regarding the view of some managers about the priority and importance of providing financial information in

36 comparison with preparing sustainability information and undervaluing the sustainability reporting, is one of the sustainability reporting challenges.

37 The lack of communication and coordination between the various participants in sustainability reporting process is one of the sustainability reporting challenges.

38 Not believing in usefulness of the sustainability reports for stakeholders, is one of the sustainability reporting challenges.

39 The lack of integrated and consensual standards for sustainability reporting is one of the sustainability reporting challenges.

40 The lack of active engagement with stakeholders to better understand their expectations and information they need is one of the challenges of sustainability reporting. 
41 Balancing the provision of quantitative and qualitative information in sustainability reports is one of the challenges of sustainability reporting.

42 The lack of required information systems infrastructure is one of the challenges of sustainability reporting.

43 The cost of providing sustainability reports, especially for small companies, is one of the challenges of sustainability reporting.

44 Consequences of disclosing sustainability information are other challenges of sustainability reporting.

Question 6: How can companies maximize the benefits of sustainability reporting?

45 Companies can benefit more from sustainability reporting when they report on a voluntary basis.

46 Companies can benefit more from sustainability reporting when they report based on well-known international standards.

47 Companies can benefit more from sustainability reporting when they benchmark the well-known similar companies.

48 Companies can benefit more from sustainability reporting when stakeholders participate in the process of preparing sustainability reports and their needs and expectation is considered.

49 Companies can benefit more from sustainability reporting when sustainability reports are audited.

50 Companies can benefit more from sustainability reporting when information systems and reporting processes are built on an appropriate infrastructure

51 Companies can benefit more from sustainability reporting by strengthening management attitudes in all aspects of sustainable performance.

Question 7: Should sustainability reports be audited?

52 Sustainability reports should be subject to independent auditing like corporate financial statements.

53 Due to agency problem between companies' owners and manages as well as information asymmetry within them, sustainability reports should be independently audited like financial information.

54 Because the audited/ assured information is more reliable in making decisions, sustainability reports should be independently audited.

55 Due to the possibility of litigation against companies for the misleading content of sustainability reports and the need to consider insurance coverage for that, sustainability reports should be subject to independent audits.

56 Due to the increased credibility of audited/ assured sustainability reports, sustainability reports should be independent audits.

57 The sustainability reports of big companies should be audited/ assured, whereas this is not necessary for small companies.

58 The sustainability reports of the companies among sensitive industries to sustainability issues should be audited/ assured, whereas others should not.

59 The sustainability reports of the companies under media and public pressure should be audited/ assured, whereas others should not.

60 The sustainability reports of the companies in the countries concerned about the rights of stakeholders should be audited/ assured, whereas others should not.

61 Because the audited/ assured sustainability reports contribute to the companies' value, sustainability reports should be independently audited.

Due to the lack of local/national standards for sustainability reporting, independent audit of sustainability reports is not possible.

63 Due to the lack of certified auditors in the field of sustainability reports auditing, independent audit of sustainability reports is not possible.

64 Due to high costs for auditing of sustainability reports, independent audit of sustainability reports is not wise.

65 Since the existing systems and processes are incapable of supporting the audit of sustainability reports, there is no need for independent auditing of sustainability reports.

66 Due to the lack of mandatory rules and regulations, there is no need for independent auditing of sustainability reports.

Due to the risk of issuing qualified or even adverse opinion on sustainability reports, there is no need for independent auditing of sustainability reports.

Due to the lack of consensus auditing standards for sustainability reports, there is no need for independent auditing of sustainability reports.

69 Due to alternative procedures, there is no need for independent auditing of sustainability reports.

70 The internal audit engagement in sustainability reporting audit is considered as one of the alternatives to the 
independent audit of sustainability reports.

71 Verification through certification such as ISO 26000, is one of the alternatives to the independent audit of sustainability reports.

Communication with stakeholders and taking their views and opinions about companies' sustainable performance is one of the alternatives to the independent audit of sustainability reports.

\section{References}

[1] Dyllick, T., Hockerts, K., 2002. Beyond the business case for corporate sustainability. Business Strategy and The Environment 11, 130-141.

[2] Rezaee, Z. (2016). Business sustainability research: A theoretical and integrated perspective. Journal of Accounting Literature, 36, 48-64.

[3] Hahn, R., \& Kühnen, M. (2013). Determinants of sustainability reporting: a review of results, trends, theory, and opportunities in an expanding field of research. Journal of cleaner production, 59, 5-21.

[4] McNally, M. A., Cerbone, D., \& Maroun, W. (2017). Exploring the challenges of preparing an integrated report. Meditari Accountancy Research, 25 (4), 481-504.

[5] KPMG (2011), "KPMG international survey of corporate responsibility reporting", available at: www.kpmg.com/PT/pt/IssuesAndInsights/Documents/corpora te-responsibility2011.pdf (accessed 29September 2014).

[6] KPMG (2013), "The KPMG survey of corporate responsibility reporting", available at: www.kpmg.com/Global/en/IssuesAndInsights/ArticlesPublica tions/corporate-responsibility/Documents/corporateresponsibility-reporting-survey-2013-exec-summary.pdf (accessed 1 October 2014).

[7] Sierra, L., Zorio, A. and Garcia-Benau, M. A. (2013), "Sustainable development and assurance of corporate social responsibility reports published by Ibex-35 companies", Corporate Social Responsibility and Environmental Management, Vol. 20 No. 6, pp. 359-370.

[8] Simnett, R., Vanstraelen, A., \& Chua, W. F. (2009). Assurance on general purpose non-financial reports: an international comparison. The Accounting Review, 84 (3), 937-967.

[9] Zorio, A., Garcia-Benau, M. A. and Sierra, L. (2013), "Sustainable development and the quality of assurance reports: empirical evidence", Business Strategy and the Environment, Vol. 22 No. 7, pp. 484-500.

[10] Cho, C. H., Laine, M., Roberts, R. W. \& Rodrigue, M. (2015). Organized hypocrisy, organizational façades, and sustainability reporting. Accounting, Organizations and Society, 40 (0), 78-94.

[11] Fakhari H, Malekian E, Jafaei Rahni M. (2018). Explaining and Ranking of the Components and Indicators of Environmental, Social and Corporate Governance Reporting by Analytic Hierarchy Process in the Companies Listed in Stock Exchange. Iranian Journal of value and behavioral accounting. 2 (4): 153-187. (in Persian)

[12] Masoumi, S. R., Salehnejad, S. H., Zabihi Zarin Kalayee, A.
(2018). Identifying the variables affecting the sustainability reporting of listed companies in Tehran Stock Exchange. Journal of Audit Science. 18 (70): 195-22 (in Persian)

[13] Mahdavi, G. H., Abbas Ali Daryaei, A. A., Alikhani, R., and Maranjory, M. (2015). The Relation of Firm Size, Industry Type and Profitability to Social and Environmental Information Disclosure. Journal of Empirical Research in Accounting. 4 (3): 87-103. doi: 10.22051/jera.2015.1994 (in Persian)

[14] Fortanier, F., Kolk, A., Pinkse, J., (2011). Harmonization in CSR reporting: MNEs and global CSR standards. Management International Review 51, 665-696.

[15] Gallo, P. J., Jones Christensen, L., (2011). Firm size matters: an empirical investigation of organizational size and ownership on sustainability-related behaviors. Business \& Society 50, 315-349.

[16] Cormier, D., Magnan, M., (2003). Environmental reporting management: a continental European perspective. Journal of Accounting and Public Policy 22, 43-62.

[17] Haniffa, R., Cooke, T. E., (2005). The impact of culture and governance on corporate social reporting. Journal of Accounting and Public Policy 24, 391-430.

[18] Kent, P., Monem, R., (2008). What drives TBL reporting: good governance or threat to legitimacy? Australian Accounting Review 18, 297-309.

[19] Haddock, J., (2005). Consumer influence on internet-based corporate communication of environmental activities: the UK food sector. British Food Journal 107 (10): 792-805.

[20] Parsa, S., Kouhy, R., (2008). Social reporting by companies listed on the alternative investment market. Journal of Business Ethics 79, 345-360.

[21] Sotorrío, L. L., Sánchez, J. L. F., 2010. Corporate social reporting for different audiences: the case of multinational corporations in Spain. Corporate Social Responsibility and Environmental Management 17, 272-283.

[22] Golob, U., Bartlett, J. L., (2007). Communicating about corporate social responsibility: a comparative study of CSR reporting in Australia and Slovenia. Public Relations Review 33, 1-9.

[23] Adams, C. A. and Evans, R. (2004), "Accountability, completeness, credibility and the audit expectations gap", The Journal of Corporate Citizenship, Vol. 14 No. 1, pp. 97-115.

[24] Park, J. and Brorson, T. (2005), Experiences of and views on third party assurance of corporate environmental and sustainability reports, Journal of Cleaner Production, Vol. 13 No. 10, pp. 1095-1106.

[25] Sawani, Y., Zain, M. M. and Darus, F. (2010), "Preliminary insights on sustainability reporting and assurance practices in Malaysia”, Social Responsibility Journal, Vol. 6 No. 4, pp. 627-645. 
[26] Mashayekhi, B. and Jalali, F. (2018). A Qualitative Study on the Vicious Cycle of Internal Audit Function in Iran. AFAANZ (Accounting and Finance Association of Australia and New Zealand) Conference, Auckland.
[27] Solomon, A. \& Lewis, L. 2002. Incentives and disincentives for corporate environmental disclosure. Business Strategy and the Environment, 11 (3), 154-169. 